\section{Inequalities in the access to healthy urban structure and housing: an analysis of the Brazilian census data}

\author{
Desigualdades no acesso a infraestrutura urbana \\ e moradia saudáveis: uma análise dos dados do \\ censo brasileiro
}

\author{
Inequidades en el acceso a entornos urbanos \\ saludables y vivienda: un análisis de datos \\ del censo brasileño
}

\begin{abstract}
This study aims (1) to test the association between access to basic sanitation/ hygiene services in Brazilian households with their householders' socioeconomic and demographic characteristics; (2) to analyze the distribution of urban health-relevant elements in the census tracts according to their income, education and race/color composition. The information come from the 2010 Brazilian Demographic Census, which collected data regarding both household conditions and urban structure of the census tracts. Prevalence ratios were calculated using crude and adjusted Poisson regression models. The proportional distribution of the census-tract urban structure was performed, according to the deciles of the exploratory variables, and the ratios and the absolute differences between the extreme deciles were calculated. Around 4.8\% of the households had no piped water, 34.7\% had no sewage collection system, 9. $8 \%$ had no garbage collection and 39\% were considered inadequate. Families whose householders were black, indigenous or brown had lower income and educational level, and lived in the North, Northeast, and Central West regions. They were more likely to be considered inappropriate for not having piped water, sewage collection system, and garbage collection. Moreover, sectors where the majority of the population was black, had lower educational levels and lower income had significantly poor paving, street lighting, afforestation, storm drain, sidewalk and wheelchair ramp. This study analyzed national data from 2010 and provides a baseline for future studies and government planning. The relevant social inequalities reported in this study need to be addressed by effective public policies.
\end{abstract}

Urban Health; Housing; Urban Sanitation; Inequalities
Antonio Fernando Boing 1

Alexandra Crispim Boing 1

S. V. Subramanian 2

doi: 10.1590/0102-311X00233119

\author{
Correspondence \\ A. F. Boing \\ Universidade Federal de Santa Catarina. \\ Campus Universitário, Florianópolis, SC 88040970, Brazil. \\ antonio.boing@ufsc.br \\ 1 Universidade Federal de Santa Catarina, Florianópolis, Brasil. \\ 2 Department of Society, Human Development and Health, \\ Harvard T. H. Chan School of Public Health, Boston, U.S.A.
}




\section{Introduction}

Considering a city with the best life expectancy in Brazil and the 2010 mortality level and standard, children should live on average 13.3 years longer than those born in cities with the worst indicator 1 . The probability of dying before the age of 1 is up to five times higher among children whose mothers live in cities with higher infant mortality compared with the opposite extreme 1. Moreover, the proportion of older adults who rate their health positively is twice higher among those who have higher education, while the prevalence of diabetes and hypertension is $80 \%$ and $124 \%$ higher in lowereducated adults, respectively 2.

Whether analyzed between individuals or geographical spaces, such inequalities are closely related to people's material living conditions, access to public services of quality, healthy working, housing and environmental conditions. The social and economic macro-determinants of health, including equality in the distribution of national wealth, determine the conditions for people to have access to information to build a healthy life ${ }^{3}$. In addition, and above all, they modulate the possibilities of accessing and performing actions that are most beneficial to health.

Researchers and policy-makers in the 21 st century have access to a vast array of scientific evidence that shows the benefits of populations having access to running water, sewage collection system and garbage collection in their homes, for example. Knowledge has also expanded on the relevance of the environmental and urban characteristics in which people live 4 . A systematic review carried out by Rachele et al. 5 identified a positive association between physical activity and pedestrian infrastructure, urban aesthetics and security against crime. Other reviews have found that exposure to worse housing conditions negatively impacts the population's mental health as they age 6 and that living in areas with more green spaces reduces death risk, especially from cardiovascular disease 7 . Conversely, poor housing quality, absence of green areas, noise and air pollution are associated with a higher prevalence of depressive mood 8; and urban structure is associated with obesity, type 2 diabetes, and hypertension 9.

Such evidence highlights the role of urban planning in improving health and well-being levels. For instance, some important targets of the Sustainable Development Goals (SDGs) are providing better housing, sanitation, increased access to green public spaces and safe transportation systems. The Shanghai Consensus on Healthy Cities in 201610 and the Copenhagen Consensus in 201811 emphasize the major role that cities and urban places play in disease prevention and health promotion. Moreover, focusing on health may trigger progress to reduce inequalities in urban areas 10.

The relevance of this discussion is particularly important when analyzing social policies in Brazil, including health. According to a World Bank compilation, 2017 national data place Brazil among the ten most unequal countries on a list of 164 nations 12 . In a country historically marked by uneven regional development, restricted access to education, patriarchal culture, income inequality and racial discrimination, inequities are also expressed in access to better living and housing conditions. In addition, as pointed out by Santos 13,14, the urban space is a process and a product of social relations and political economy. Despite their relevance to the health of populations, especially in a country as unequal as Brazil, there are no studies that analyze access to urban and housing characteristics impacting on health throughout the national territory, according to the socioeconomic and demographic attributes of the population.

The aim of the present study is to analyze national data from the most recent national census and provide a baseline for future studies and government planning by (i) testing the association between access to basic sanitation/hygiene services in Brazilian houses with their householders' socioeconomic and demographic characteristics and (ii) analyzing the distribution of urban health-relevant elements in the Brazilian census tracts, according to their income, education and race/color composition. 


\section{Methods}

The data analyzed come from the 2010 Brazilian Demographic Census conducted from August 1 to October 30, 2010. Census sample data and pre-collection data were included in this study.

\section{Census sample data}

In the 2010 census, two questionnaires were applied: one basic that was used in all households in the country, and another more detailed, used in a previously selected sample. This last questionnaire expanded the information collected about household characteristics and social, economic and demographic aspects of their residents. To calculate and select the sample of the households, the sizes of the municipalities were considered, and five sampling fractions were applied according to the population size of the municipalities. The effective sample fraction was $10.7 \%$ of households for the country as a whole.

In the selected households, data were collected through face-to-face interviews conducted by the census taker. The answers were either recorded on a handheld computer or via Internet by completing the questionnaire if the resident opted for this modality. In the present study, we analyzed the occupied private households located in an urbanized area. To reach the results, As outcome, the following variables related to the households were considered: (1) piped water in at least one room; (2) waste collection directly by the cleaning service; (3) sewage or rainwater collection system; (4) inadequate housing. As defined by Brazilian Institute of Geography and Statistics (IBGE) , a house is considered inadequate when at least one of the following parameters is not present: up to two residents per dormitory; water supply through the general distribution network; sewage or rainwater collection system or, at least, septic tank; and garbage collected directly by a cleaning service or in a dumpster. More details on the 2010 census sample data collection are provided elsewhere 15 .

Exploratory variables related to the householder were: gender (male and female), region of residence (North, Northeast, Central West, Southeast, South), self-reported skin color/race (black, brown, yellow, indigenous, white), household income per capita (categorized in quintiles) and educational level (complete higher education, incomplete higher education, incomplete high school and incomplete elementary school). Thus, the analysis units were the householders associated with the characteristics of their household units.

\section{Census pre-collection data}

In the 2010 census, there was a preliminary stage to the collection itself. Called pre-collection, it was carried out through on-site visit by census takers to the census tracts under their responsibility. The main objective was to elaborate the address listing, updating the maps and registering all existing addresses. Additionally, information about the block-faces was collected to describe the urban structure of the addresses.

Among the urban characteristics of the surroundings that were collected by IBGE, the present study analyzed the presence of: (1) street lighting (existence of at least one street lamp); (2) road paving (roadway covering with asphalt, cement, cobblestones, stones or other material); (3) afforestation (existence of tree along the sidewalk and/or in a street flowerbed that divides lanes of the same street. The existence of a tree was considered even when there was no paving or sidewalk); (4) storm drain (an opening on the streets that is designed to drain excess rain and groundwater); (5) sidewalk (paved path intended for pedestrian traffic); and (6) wheelchair ramp (curb or lowered-curb specifically for wheelchair users). As for street lighting, afforestation and storm drain, the presence of these items was considered on the working, and regarding the presence of sidewalk and wheelchair ramp, only the sidewalk was analyzed. The data on the urban characteristics of the household surroundings were recorded only during the "census pre-collection field". More methodological details of this step of the national census are provided elsewhere 16 .

The study included permanent private households in urbanized areas of the city or village and those in isolated urban areas. Data were grouped by census tract, which was the analysis unit. The 
variables sidewalk, road paving, storm drain and afforestation were categorized as follows: $0 \%$ of households in the sector presented the characteristic; $0.1 \%$ to $33.3 \%$; $33.4 \%$ to $66.6 \%$; $66.7 \%$ to $99.9 \%$ and $100 \%$. The variable street lighting was divided into $0 \%$ to $66.6 \% ; 66.7 \%$ to $90 \% ; 90.1 \%$ to $99.9 \%$ and $100 \%$. Finally, the wheelchair ramp variable was categorized as $0 \%$; $0.1 \%$ to $10 \% ; 10.1 \%$ to $33.3 \%$ and $33.4 \%$ to $100 \%$.

The exploratory variables were the composition of the census tracts, according to the proportion of the black population (browns plus blacks), the distribution of per capita income of people aged 10 years and over and the illiteracy percentage among people aged 15 years and over. These three variables were categorized into deciles according to their distribution, organizing the census tracts into ten groups based on their proportion of blacks, their income and their literacy level.

\section{Data analysis}

The data allowed the proportional calculation of the absences of: piped water at home, sewage collection system, garbage collection and inadequate household. In addition to the proportional distribution of these outcomes among the categories of exploratory variables, prevalence ratios (PR) with respective 95\% confidence intervals (95\%CI) were calculated using crude and adjusted Poisson regression models. Sample weights were included in all analyses. Concerning the pre-collection data, we performed the proportional distribution of the outcomes according to the deciles of the exploratory variables, and calculated the ratio and the absolute difference between the extreme deciles. We also calculated two complex measures to summarize inequality across the socioeconomic and demographic groups. The Slope Index of Inequality and the Concentration Index were estimated as measures of absolute and relative inequality, respectively 17 . Both were reported with their standard errors and the data were analyzed using Stata 15.1 (https://www.stata.com).

All data analyzed are public and anonymized, making the identification of the respondents impossible. The datasets are available online (https://censo2010.ibge.gov.br/resultados.html). Thus, there was no need for consideration by the Ethics Research Committee.

\section{Results}

We analyzed data from 227,597 census tracts and 4,673,222 households and householders from 5,565 municipalities in urban regions of Brazil. The absence of piped water and garbage collection were observed in $4.8 \%$ and $9.8 \%$ of households, respectively (Table 1). In the Northern region, approximately one in six households did not have these services. The worst situation was verified as for the sewage collection system access. Just over one in three households analyzed had no coverage, which exceeded half of them in the Central West, Northeast and North (where the value reached 81.4\%). Inadequate housing reached $39 \%$ in the national analysis, ranging from $26 \%$ in the Southeast to $78.9 \%$ in the North.

As the analysis of inequalities expands, access to all services is found to be worse in households headed by lower-income and lower-education people, brown, black and indigenous compared with white, and among residents of the Central Western, Northeastern and Northern regions (Tables 2 and 3).

In the adjusted analysis, it was observed that among the poorest quintile, the absence of piped water was $152 \%$ higher than the households headed by the richest group (Table 3 ). When analyzing the household inadequacy, the percentage was $187 \%$ higher. A similar pattern was observed when considering the householder's education, although the magnitude of the prevalence ratios was lower. In all cases, a distinct socioeconomic gradient could be observed. All indicators were also worse among those who reported skin color/race other than white. The absence of piped water was $71 \%$ higher among indigenous people, and the absence of garbage collection was $43 \%$ higher among families whose householders self-declared as black. The highest PR magnitudes were observed when analyzing the residence regions. The absence of sewage collection system was 5.7 times higher in the North and the absence of garbage collection was 2.46 times higher in the Northeast compared with the Southeast. Finally, all the prevalence ratios were higher when the householder was male. 
Table 1

Proportion of private urban households with no piped water, sewage collection system, garbage collection and considered inadequate, according to the householder's characteristics. Brazil, 2010.

\begin{tabular}{|c|c|c|c|c|}
\hline \multirow[t]{2}{*}{ Characteristics } & \multicolumn{4}{|c|}{ system } \\
\hline & $\%(95 \% \mathrm{Cl})$ & $\%(95 \% \mathrm{CI})$ & $\%(95 \% \mathrm{Cl})$ & $\%(95 \% \mathrm{Cl})$ \\
\hline Brazil & $4.8(4.8-4.9)$ & $34.7(34.7-34.8)$ & $9.8(9.7-9.8)$ & $39.0(39.0-39.1)$ \\
\hline \multicolumn{5}{|l|}{ Gender } \\
\hline Men & $5.0(5.0-5.0)$ & $34.1(34.0-34.2)$ & $10.1(10.1-10.2)$ & 38.6 (38.5-38.7) \\
\hline Women & $4.8(4.7-4.8)$ & $35.1(35.1-35.2)$ & $9.5(9.5-9.5)$ & $39.4(39.3-39.4)$ \\
\hline \multicolumn{5}{|l|}{ Region } \\
\hline Southeast & $2.6(2.6-2.6)$ & $12.7(12.7-12.8)$ & $6.5(6.4-6.5)$ & $26.0(26.0-26.1)$ \\
\hline South & $1.4(1.4-1.5)$ & $45.6(45.5-45.7)$ & $4.4(4.4-4.5)$ & $31.3(31.2-31.4)$ \\
\hline Central West & $4.2(4.1-4.3)$ & $56.2(56.1-56.4)$ & $7.4(7.3-7.6)$ & $52.9(52.7-53.1)$ \\
\hline Northeast & $8.6(8.5-8.6)$ & $54.0(54.0-54.2)$ & $19.4(19.3-19.4)$ & $55.9(55.0-56.0)$ \\
\hline North & $17.9(17.8-18.1)$ & $81.4(81.2-81.6)$ & $15.9(15.8-16.0)$ & 78.9 (78.7-79.0) \\
\hline \multicolumn{5}{|l|}{ Skin color/race } \\
\hline White & $2.9(2.9-2.9)$ & $28.3(28.4-28.4)$ & $6.8(6.8-6.9)$ & $29.2(29.2-29.3)$ \\
\hline Asian & $5.2(5.0-5.4)$ & $31.5(31.2-31.8)$ & $10.0(9.7-10.2)$ & $34.8(34.5-35.2)$ \\
\hline Brown & $7.0(6.9-7.0)$ & $42.9(42.8-42.9)$ & $12.6(12.6-12.6)$ & $50.2(50.1-50.2)$ \\
\hline Black & $6.7(6.6-6.8)$ & $36.2(36.1-36.4)$ & $13.9(13.8-14.0)$ & $47.0(46.8-47.1)$ \\
\hline Indigenous & $10.4(9.9-11.0)$ & $45.9(45.1-46.7)$ & $13.5(12.9-14.2)$ & $51.5(50.6-52.5)$ \\
\hline \multicolumn{5}{|l|}{ Income (quintiles) } \\
\hline 5 (richest) & $2.0(1.9-2.0)$ & $20.5(20.4-20.6)$ & $6.4(6.3-6.4)$ & $15.4(15.4-15.5)$ \\
\hline 4 & $2.8(2.7-2.8)$ & $29.3(29.2-29.3)$ & $6.4(6.3-6.4)$ & $28.5(28.4-28.6)$ \\
\hline 3 & $4.1(4.0-4.1)$ & $35.8(35.7-25.9)$ & $8.8(8.7-8.8)$ & $39.9(39.8-40.0)$ \\
\hline 2 & $5.4(5.4-5.5)$ & $42.5(42.4-42.6)$ & $11.3(11.2-11.3)$ & $53.9(53.8-54.0)$ \\
\hline 1 (poorest) & $11.2(11.1-11.2)$ & $50.6(50.5-50.7)$ & $17.4(17.4-17.5)$ & $65.5(65.4-65.3)$ \\
\hline \multicolumn{5}{|l|}{ Educational level } \\
\hline Complete higher education & $1.8(1.7-1.8)$ & $19.3(19.2-19.4)$ & $7.0(6.9-7.1)$ & $15.1(15.0-15.2)$ \\
\hline Incomplete higher education & $3.0(3.0-3.1)$ & $30.0(30.0-30.1)$ & $7.7(7.6-7.8)$ & $32.2(32.1-32.3)$ \\
\hline Incomplete high school & $4.4(4.3-4.4)$ & $34.6(34.5-34.7)$ & $8.7(8.6-8.8)$ & $41.3(41.2-41.4)$ \\
\hline Incomplete elementary school & $6.8(6.8-6.9)$ & $41.6(41.6-41.7)$ & $12.0(12.0-12.1)$ & $48.5(48.5-48.6)$ \\
\hline
\end{tabular}

95\% Cl: 95\% confidence interval.

* Failure to have at least one of the following parameters: up to two residents per dormitory; water supply through the general distribution system; sanitary sewage through sewage or septic tank; and garbage collected directly by public service or by dumpster.

Taking the census tracts as the analysis unit, it was observed that $22.5 \%$ of the households had no storm drain, and $79.5 \%$ had no sidewalk ramp for wheelchair access (Table 4). In addition, paving (22.1\%) and afforestation (33.7\%) were observed in less than two-thirds of the households. Almost a quarter of the census tracts showed less than $33.3 \%$ of households with sidewalk coverage. The best indicator observed was street lighting (62.6\% of the sectors had $100 \%$ of household coverage).

Table 5 analyzes the distribution of urban characteristics according to the ethnic/racial and socioeconomic composition of the census tracts. The inequalities observed were remarkable. Regarding the lowest-income decile, the census tracts showed $9.6 \%$ of households had no street paving, whereas in the richest decile the 32 figure reached $0.3 \%$, corresponding to a 32 -fold difference. As for the presence of a sidewalk, $5.1 \%$ of the poorest sectors presented a $100 \%$ coverage of households compared with $78.5 \%$ of the highest-income decile. The same phenomenon was observed when analyzing the educational level. The proportion of fully-covered sectors for ramps for wheelchair users was 73 times higher in the decile of inhabitants of higher educational levels. The total absence of storm 
Table 2

Crude prevalence ratios of the association between household characteristics and householder's demographic and socioeconomic characteristics. Brazil, 2010.

\begin{tabular}{|c|c|c|c|c|}
\hline \multirow[t]{2}{*}{ Characteristics } & \multirow{2}{*}{\multicolumn{4}{|c|}{$\begin{array}{c}\text { system } \\
\text { PR }(95 \% \mathrm{Cl})\end{array}$}} \\
\hline & & & & \\
\hline \multicolumn{5}{|l|}{ Gender } \\
\hline Men & 1.00 & 1.00 & 1.00 & 1.00 \\
\hline Women & $0.95(0.94-0.96)$ & $1.03(1.03-1.03)$ & $0.94(0.93-0.95)$ & $1.02(1.01-1.02)$ \\
\hline \multicolumn{5}{|l|}{ Region } \\
\hline Southeast & 1.00 & 1.00 & 1.00 & 1.00 \\
\hline South & $0.55(0.54-0.57)$ & $3.58(3.56-3.60)$ & $0.68(0.68-0.69)$ & $1.20(1.20-1.20)$ \\
\hline Central West & $1.62(1.58-1.65)$ & $4.42(4.40-4.44)$ & $1.15(1.13-1.17)$ & $2.03(2.02-2.04)$ \\
\hline Northeast & $3.29(3.25-3.33)$ & $4.24(4.23-4.26)$ & $2.99(2.97-3.01)$ & $2.14(2.14-2.15)$ \\
\hline North & $6.90(6.81-6.99)$ & $6.39(6.37-6.42)$ & $2.46(2.43-2.48)$ & $3.03(3.02-3.04)$ \\
\hline \multicolumn{5}{|l|}{ Skin color/race } \\
\hline White & 1.00 & 1.00 & 1.00 & 1.00 \\
\hline Asian & $1.80(1.72-1.87)$ & $1.11(1.10-1.13)$ & $1.46(1.42-1.50)$ & $1.19(1.18-1.21)$ \\
\hline Brown & $2.40(2.38-2.43)$ & $1.51(1.51-1.52)$ & $1.84(1.83-1.86)$ & $1.72(1.71-1.72)$ \\
\hline Black & $2.32(2.29-2.36)$ & $1.28(1.27-1.28)$ & $2.04(2.02-2.06)$ & $1.60(1.60-1.61)$ \\
\hline Indigenous & $3.60(3.39-3.82)$ & $1.62(1.58-1.66)$ & $1.98(1.88-2.08)$ & $1.76(1.72-1.80)$ \\
\hline \multicolumn{5}{|l|}{ Income (quintiles) } \\
\hline 5 (richest) & 1.00 & 1.00 & 1.00 & 1.00 \\
\hline 4 & $1.40(1.37-1.43)$ & $1.43(1.42-1.43)$ & $0.99(0.99-1.01)$ & $1.85(1.84-1.86)$ \\
\hline 3 & $2.08(2.04-2.12)$ & $1.74(1.73-1.75)$ & $1.37(1.35-1.39)$ & $2.59(2.57-2.60)$ \\
\hline 2 & $2.77(2.71-2.82)$ & $2.07(2.06-2.08)$ & $1.76(1.74-1.78)$ & $3.49(3.47-3.51)$ \\
\hline 1 (poorest) & $5.68(5.58-5.78)$ & $2.46(2.45-2.48)$ & $2.73(2.70-2.76)$ & $4.24(4.22-4.27)$ \\
\hline \multicolumn{5}{|l|}{ Educational level } \\
\hline Complete higher education & 1.00 & 1.00 & 1.00 & 1.00 \\
\hline Incomplete higher education & $1.69(1.64-1.73)$ & $1.55(1.54-1.56)$ & $1.10(1.08-1.11)$ & $2.13(2.11-2.14)$ \\
\hline Incomplete high school & $2.44(2.37-2.50)$ & $1.79(1.78-1.81)$ & $1.24(1.22-1.26)$ & $2.73(2.71-2.75)$ \\
\hline Incomplete elementary school & $3.81(3.72-3.90)$ & $2.16(2.14-2.17)$ & $1.71(1.69-1.73)$ & $3.21(3.18-3.23)$ \\
\hline
\end{tabular}

95\%Cl: 95\% confidence interval; PR: prevalence ratio.

* Failure to have at least one of the following parameters: up to two residents per dormitory; water supply through the general distribution system; sanitary sewage through sewage or septic tank; and garbage collected directly by public service or by dumpster.

drain was $43.2 \%$ higher in the decile of lower education. The inequality pattern was repeated when categorizing the sectors in deciles according to the proportion of black residents. The proportion of afforestation in all households was almost seven times higher in the decile of the lower proportion of blacks. The total presence of sidewalks was observed in only $2.4 \%$ of the sectors of the decile of the highest proportion of blacks compared with $24.3 \%$ of the decile with the lowest proportion. All the calculated concentration and slope indexes of inequity also indicated that better coverages of the analyzed urban settings were observed among census tracts of the richest, the highest educated residents and the lowest proportion of black inhabitants (Table 5). 
Table 3

Adjusted prevalence ratios of the association between household characteristics and householder's demographic and socioeconomic characteristics. Brazil, 2010.

\begin{tabular}{|c|c|c|c|c|}
\hline \multirow[t]{2}{*}{ Characteristics } & No piped water & $\begin{array}{c}\text { No sewage collection } \\
\text { system }\end{array}$ & No garbage collection & Inadequate household * \\
\hline & PR $(95 \% \mathrm{Cl})$ & PR $(95 \% \mathrm{Cl})$ & PR (95\%Cl) & PR $(95 \% \mathrm{Cl})$ \\
\hline \multicolumn{5}{|l|}{ Gender } \\
\hline Men & 1.00 & 1.00 & 1.00 & 1.00 \\
\hline Women & $1.04(1.03-1.05)$ & $1.08(1.08-1.08)$ & $1.01(1.00-1.01)$ & $1.09(1.09-1.09)$ \\
\hline \multicolumn{5}{|l|}{ Region } \\
\hline Southeast & 1.00 & 1.00 & 1.00 & 1.00 \\
\hline South & $0.62(0.60-0.63)$ & $3.72(3.71-3.74)$ & $0.74(0.74-0.75)$ & $1.30(1.30-1.31)$ \\
\hline Central West & $1.53(1.50-1.57)$ & $4.30(4.28-4.32)$ & $1.11(1.09-1.13)$ & $1.94(1.93-1.95)$ \\
\hline Northeast & $2.40(2.37-2.43)$ & $3.71(3.70-3.73)$ & $2.46(2.44-2.48)$ & $1.66(1.66-1.67)$ \\
\hline North & $5.31(5.24-5.38)$ & $5.70(5.67-5.72)$ & $2.08(2.06-2.11)$ & $2.43(2.42-2.44)$ \\
\hline \multicolumn{5}{|l|}{ Skin color/race } \\
\hline White & 1.00 & 1.00 & 1.00 & 1.00 \\
\hline Asian & $1.30(1.25-1.35)$ & $1.00(0.99-1.02)$ & $1.18(1.15-1.22)$ & $1.04(1.03-1.05)$ \\
\hline Brown & $1.26(1.25-1.27)$ & $1.12(1.12-1.12)$ & $1.23(1.22-1.24)$ & $1.18(1.18-1.19)$ \\
\hline Black & $1.38(1.36-1.40)$ & $1.05(1.04-1.06)$ & $1.43(1.42-1.45)$ & $1.18(1.17-1.18)$ \\
\hline Indigenous & $1.71(1.62-1.81)$ & $1.07(1.05-1.09)$ & $1.29(1.23-1.36)$ & $1.15(1.13-1.18)$ \\
\hline \multicolumn{5}{|l|}{ Income (quintiles) } \\
\hline 5 (richest) & 1.00 & 1.00 & 1.00 & 1.00 \\
\hline 4 & $1.11(1.08-1.13)$ & $1.25(1.24-1.25)$ & $0.92(0.91-0.94)$ & $1.58(1.57-1.59)$ \\
\hline 3 & $1.32(1.30-1.35)$ & $1.37(1.36-1.38)$ & $1.09(1.08-1.10)$ & $2.02(2.01-2.03)$ \\
\hline 2 & $1.50(1.47-1.53)$ & $1.49(1.48-1.50)$ & $1.24(1.23-1.26)$ & $2.54(2.53-2.56)$ \\
\hline 1 (poorest) & $2.52(2.47-2.57)$ & $1.60(1.59-1.60)$ & $1.63(1.62-1.65)$ & $2.87(2.85-2.88)$ \\
\hline \multicolumn{5}{|l|}{ Educational level } \\
\hline Complete higher education & 1.00 & 1.00 & 1.00 & 1.00 \\
\hline Incomplete higher education & $1.14(1.11-1.17)$ & $1.20(1.20-1.21)$ & $0.87(0.86-0.89)$ & $1.37(1.35-1.38)$ \\
\hline Incomplete high school & $1.48(1.44-1.53)$ & $1.32(1.32-1.33)$ & $0.93(0.91-0.94)$ & $1.54(1.53-1.56)$ \\
\hline Incomplete elementary school & $1.97(1.92-2.03)$ & $1.46(1.45-1.47)$ & $1.11(1.10-1.13)$ & $1.61(1.60-1.63)$ \\
\hline
\end{tabular}

95\%Cl: 95\% confidence interval; PR: prevalence ratio.

* Failure to have at least one of the following parameters: up to two residents per dormitory; water supply through the general distribution system; sanitary sewage through sewage or septic tank; and garbage collected directly by public service or by dumpster. 
Table 4

Proportion of households in the census tract that have the urban characteristic, according to stratum of coverage. Brazil, 2010.

\begin{tabular}{lccccc}
\hline $\begin{array}{l}\text { Urban } \\
\text { characteristics }\end{array}$ & \multicolumn{5}{c}{ Proportion of households in the census tract with the respective } \\
urban characteristic (\%) \\
Coverage \\
& $\mathbf{0} \%$ & $\mathbf{0 . 1 \% - 3 3 . 3 \%}$ & $\mathbf{3 3 . 4 \% - 6 6 . 6 \%}$ & $\mathbf{6 6 . 7 \% - 9 9 . 9 \%}$ & $\mathbf{1 0 0 \%}$ \\
\hline $\begin{array}{l}\text { Paving } \\
\text { Afforestation }\end{array}$ & 3.1 & 9.4 & 9.6 & 28.2 & 49.7 \\
Storm drain & 7.4 & 14.0 & 16.3 & 39.9 & 22.4 \\
Sidewalk & 22.5 & 27.7 & 18.2 & 19.5 & 12.1 \\
\hline & 9.8 & 14.9 & 12.0 & 30.1 & 33.2 \\
\hline Wheelchair ramp & $\mathbf{0} \%$ & $\mathbf{0 . 1 \% - 1 0 \%}$ & $\mathbf{1 0 . 1 \% - 3 3 . 3 \%}$ & $\mathbf{3 3 . 4 \% - 1 0 0 \%}$ & \\
\hline & 79.5 & 10.6 & 5.0 & 4.9 & $\mathbf{1 0 0 \%}$ \\
\hline Street lighting & $\mathbf{0 \% - 6 6 . 6 \%}$ & $\mathbf{6 6 . 7 \% - 9 0 \%}$ & $\mathbf{9 0 . 1 \% - 9 9 . 9 \%}$ & \\
\hline
\end{tabular}

Table 5

Concentration Index (CIX), Slope Index of Inequality (SII) and proportion of households with the urban characteristics described according to the deciles of income distribution, education and proportion of blacks living in the census tracts. Brazil, 2010.

\begin{tabular}{|c|c|c|c|c|c|c|c|c|}
\hline & \multicolumn{2}{|c|}{$\begin{array}{l}\text { No coverage/low } \\
\text { coverage * }(\%)\end{array}$} & \multirow{2}{*}{$\begin{array}{l}\text { Ratio (\%) } \\
\text { D1/D10 }\end{array}$} & \multirow{2}{*}{$\begin{array}{c}\text { Difference } \\
\text { (\%) } \\
\text { D1-D10 }\end{array}$} & \multicolumn{2}{|c|}{$\begin{array}{l}\text { No coverage/low } \\
\text { coverage * }(\%)\end{array}$} & \multirow{2}{*}{$\begin{array}{l}\text { Ratio (\%) } \\
\text { D1/D10 }\end{array}$} & \multirow{2}{*}{$\begin{array}{c}\text { Difference } \\
\text { (\%) } \\
\text { D1-D10 }\end{array}$} \\
\hline & D1 & D10 & & & D1 & D10 & & \\
\hline \multicolumn{9}{|l|}{$\begin{array}{l}\text { According to income } \\
\text { deciles }\end{array}$} \\
\hline Paving & 9.6 & 0.3 & 32.0 & 9.3 & 10.7 & 88.9 & 8.3 & 78.2 \\
\hline Street lighting & 8.3 & 1.0 & 8.3 & 7.3 & 28.0 & 91.5 & 3.3 & 63.5 \\
\hline Afforestation & 10.7 & 3.7 & 2.9 & 7.0 & 8.2 & 59.2 & 7.3 & 51.1 \\
\hline Storm drain & 57.5 & 9.9 & 5.8 & 47.6 & 1.0 & 41.4 & 41.4 & 40.4 \\
\hline Sidewalk & 25.7 & 1.8 & 14.3 & 23.9 & 5.1 & 78.5 & 15.4 & 73.4 \\
\hline Wheelchair ramp & 93.0 & 53.8 & 1.7 & 39.2 & 0.0 & 11.3 & 376.6 & 11.3 \\
\hline \multicolumn{9}{|c|}{$\begin{array}{l}\text { According to the deciles } \\
\text { of schooling }\end{array}$} \\
\hline Paving & 7.1 & 1.6 & 4.4 & 5.5 & 10.1 & 87.6 & 8.7 & 77.5 \\
\hline Street lighting & 6.2 & 1.8 & 3.4 & 4.4 & 26.0 & 91.0 & 3.5 & 65.0 \\
\hline Afforestation & 5.8 & 6.3 & 0.9 & -0.5 & 8.9 & 56.5 & 6.3 & 47.6 \\
\hline Storm drain & 55.4 & 12.2 & 4.5 & 43.2 & 0.4 & 41.5 & 103.8 & 41.1 \\
\hline Sidewalk & 19.4 & 4.2 & 4.6 & 15.2 & 5.0 & 75.6 & 14.8 & 70.5 \\
\hline Wheelchair ramp & 88.8 & 61.5 & 1.4 & 27.3 & 0.0 & 10.3 & 343.3 & 10.3 \\
\hline
\end{tabular}

(continues) 


\begin{tabular}{|c|c|c|c|c|c|c|c|c|}
\hline & \multicolumn{2}{|c|}{$\begin{array}{l}\text { No coverage/low } \\
\text { coverage * }(\%)\end{array}$} & \multirow{2}{*}{$\begin{array}{l}\text { Ratio (\%) } \\
\text { D1/D10 }\end{array}$} & \multirow{2}{*}{$\begin{array}{l}\text { Difference } \\
\qquad(\%) \\
\text { D1-D10 }\end{array}$} & \multicolumn{2}{|c|}{$\begin{array}{l}\text { No coverage/low } \\
\text { coverage * }(\%)\end{array}$} & \multirow{2}{*}{$\begin{array}{l}\text { Ratio (\%) } \\
\text { D1/D10 }\end{array}$} & \multirow{2}{*}{$\begin{array}{l}\text { Difference } \\
\text { (\%) } \\
\text { D1-D10 }\end{array}$} \\
\hline & D1 & D10 & & & D1 & D10 & & \\
\hline \multicolumn{9}{|c|}{$\begin{array}{l}\text { According to the deciles } \\
\text { of black proportion of } \\
\text { residents }\end{array}$} \\
\hline Paving & 2.2 & 6.8 & 3.1 & 4.6 & 67.0 & 20.5 & 3.3 & 46.5 \\
\hline Street lighting & 1.8 & 7.2 & 4.0 & 5.4 & 78.5 & 37.7 & 2.1 & 40.8 \\
\hline Afforestation & 4.3 & 15.6 & 3.6 & 11.3 & 43.3 & 6.3 & 6.9 & 37.0 \\
\hline Storm drain & 10.3 & 45.2 & 4.4 & 34.9 & 24.3 & 2.4 & 10.1 & 21.9 \\
\hline Sidewalk & 7.6 & 23.4 & 3.1 & 15.8 & 52.0 & 7.9 & 6.6 & 44.1 \\
\hline \multirow[t]{2}{*}{ Wheelchair ramp } & 61.9 & 91.6 & 1.5 & 29.7 & 5.3 & 0.0 & 176.7 & 5.3 \\
\hline & \multicolumn{2}{|c|}{$\mathrm{CIX}(\mathrm{SE})$} & \multicolumn{2}{|c|}{ SII (SE) } & \multicolumn{2}{|c|}{ CIX (SE) } & \multicolumn{2}{|c|}{ SII (SE) } \\
\hline \multicolumn{9}{|l|}{$\begin{array}{l}\text { According to income } \\
\text { deciles }\end{array}$} \\
\hline Paving & \multicolumn{2}{|c|}{$-47.93(0.55)$} & \multicolumn{2}{|c|}{$-10.25(0.20)$} & \multicolumn{2}{|c|}{$25.86(0.11)$} & \multicolumn{2}{|c|}{$72.18(0.21)$} \\
\hline Street lighting & \multicolumn{2}{|c|}{$-37.92(0.60)$} & \multicolumn{2}{|c|}{$-8.11(0.18)$} & \multicolumn{2}{|c|}{$16.70(0.09)$} & \multicolumn{2}{|c|}{$60.54(0.26)$} \\
\hline Afforestation & \multicolumn{2}{|c|}{$-23.58(0.41)$} & \multicolumn{2}{|c|}{$-10.37(0.21)$} & \multicolumn{2}{|c|}{$32.56(0.21)$} & \multicolumn{2}{|c|}{$43.94(0.29)$} \\
\hline Storm drain & \multicolumn{2}{|c|}{$-33.64(0.21)$} & \multicolumn{2}{|c|}{$-45.00(0.29)$} & \multicolumn{2}{|c|}{$45.82(0.28)$} & \multicolumn{2}{|c|}{$36.38(0.29)$} \\
\hline Sidewalk & & & -26.9 & $9(0.27)$ & & & 68.3 & $(0.22)$ \\
\hline Wheelchair ramp & & & -39.0 & $9(0.29)$ & & & 17.1 & $(0.52)$ \\
\hline $\begin{array}{l}\text { According to the decil } \\
\text { of schooling }\end{array}$ & & & & & & & & \\
\hline Paving & & & -7.92 & $(0.17)$ & & & 74.9 & $(0.20)$ \\
\hline Street lighting & & & -6.6 & $(0.16)$ & & & 64.7 & $(0.24)$ \\
\hline Afforestation & & & -2.17 & $(0.18)$ & & & 40.0 & $(0.30)$ \\
\hline Storm drain & & & -44.2 & $(0.30)$ & & & 41.6 & $(0.30)$ \\
\hline Sidewalk & & & -21.5 & $(0.25)$ & & & 70.6 & $(0.22)$ \\
\hline Wheelchair ramp & & & -25.2 & $8(0.30)$ & & & 15.4 & $(0.42)$ \\
\hline $\begin{array}{l}\text { According to the decil } \\
\text { of proportion of black } \\
\text { residents }\end{array}$ & & & & & & & & \\
\hline Paving & & & 4.88 & $(0.16)$ & & & -50.2 & $(0.30)$ \\
\hline Street lighting & & & 5.40 & $(0.16)$ & & & -42.0 & $(0.32)$ \\
\hline Afforestation & & & 14.0 & $(0.23)$ & & & -42.8 & $(0.28)$ \\
\hline Storm drain & & & 40.6 & $(0.29)$ & & & -22.0 & $(0.25)$ \\
\hline Sidewalk & & & 14.9 & $(0.26)$ & & & -47.9 & $(0.29)$ \\
\hline Wheelchair ramp & & & 31.3 & $(0.29)$ & & & -7.1 & $(0.17)$ \\
\hline
\end{tabular}

D1: decile 1; D10: decile 10; SE: standard error.

* For the variables sidewalk, paving, storm drain, wheelchair ramp and afforestation, "No coverage/low coverage" was considered when 0\% of households in the sector did not have the characteristic. For the street lighting variable, "No coverage/low coverage" corresponded to a coverage of $0 \%$ to $66.6 \%$. 


\section{Discussion}

The present study identified deep inequalities concerning the access to adequate urban and home structures. Families whose householders were black, indigenous or brown, had both lower income and education, and lived in the North, Northeast or Central West were more likely to be considered inappropriate for not having piped water, sewage collection system or garbage collection. Moreover, census sectors where the majority of the population was black, had both lower education and income had a significantly lower coverage of paving, street lighting, afforestation, storm drains, sidewalks or wheelchair ramps.

Studies carried out in other countries have also identified inequalities in the access to better-structured housing. Gasteyer et al. 18 analyzed US data and found that places with higher percentages of unemployed people, lower educational attainment, populated by American Indians or Alaska Natives were more likely to not have access to complete plumbing facilities. Geographic inequalities and a higher concentration of access to improved water and sanitation among the wealthier households were also reported in Nigeria ${ }^{19}$, Zambia 20 and Latin America 21.

Fuller et al. 22 analyzed data from dozens of countries and explored temporal patterns in access to drinking water and sanitation around the world. The authors observed heterogeneous patterns among the countries. Most of them improved the access linearly over the Millennium Development Goal (MDG) period, but others exhibited non-linear trajectories or a linear decline, likely due to rapid urbanization. Even in countries where better access to basic sanitation/hygiene services has been achieved, the inequalities must be surveilled. In the Eastern Mediterranean region, most countries report that the national sanitation and water supply policies specifically include measures for the poor 10 . Nonetheless, less than half of them has tracked progress in extending services for the poor and only one out of five has consistently applied financial measures to reduce the disparity between the rich and the poor.

In Brazil, urban conditions improved substantially from 1960 to 2010. During this period, it was possible to observe a reduction of inequalities in the access to better urban conditions. However, the differences between socioeconomic groups and regions are still too large, even with the 1988 Federal Constitution that recognizes health as a fundamental right and a responsibility of the State, and the National Basic Sanitation Plan whose mission is to reduce regional inequalities.

The fact is that during the rapid urbanization experienced in Brazil in the 20th century, the occupation of urban territories was marked by important spatial and economic segregation 14 . The lack of planning in Brazilian cities, the absence of individual rights of the underprivileged and the deep socioeconomic inequality of Brazilian society have made the black population and poorer groups occupy territories with little basic infrastructure along the History. The large number of migrants who flocked to the cities in the 20th century did not have access to the private housing market and did not benefit from public housing policies either 23 . As a consequence, the occupation of undeveloped land without public services has been quite common for many decades. Government actions to reverse this scenario have been scarce and greatly influenced or limited by the strong counter-lobbying of economic groups interested in the most highly valued land.

Duarte et al. 24 highlight that the new plots of land marketed to the poorest social classes are approximately $250 \mathrm{~m}^{2}$ in size, with both narrow streets and sidewalks to lower the costs of the project. These dimensions make the access to urban green spaces difficult to the population, and good levels of afforestation are not achieved. Regarding urban afforestation, this is a relatively new practice in Brazil and has been historically and empirically practiced, rarely within a technical-scientific context 25. Moreover, Sartori et al. 26 analyzed the urban afforestation of a favela in Brazil and found two major differences from the one observed in more affluent neighborhoods. According to the authors, in the richest regions of the city, afforestation follows a pattern of landscape influence, with significant aesthetic concerns. On the other hand, the public sector has little influence in the favela, where most species are planted in the backyards of the houses and urban afforestation is rare either because there are few sidewalks or because they are too narrow.

In 2016, 27.2\% of the municipalities were affected by flash floods. This figure reached $61.9 \%$ among the municipalities with 100,000 to 500,000 inhabitants 27 . It is noteworthy that only $3.7 \%$ of the municipalities have a specific law that discusses flooding prevention or flash floods. It is worry- 
ing that $22.5 \%$ of the census tracts analyzed in this study have no storm drains, a figure that doubles in the poorest census tracts. The momentary accumulation of water in a flash flood usually occurs due to poor drainage systems. The absence of good storm drains/drainage systems plus the garbage accumulation contribute to catastrophic situations that are more likely to affect the most vulnerable populations that live in areas without appropriate urban structures.

It is estimated that around 6.7 billion people will live in cities by 2050. Thus, benchmarking, monitoring and evaluating city planning policies and interventions is critical to achieve good urban and health outcomes 28 . Far beyond individual choices, people's behaviors are influenced by the economic, social, cultural and environmental conditions in which they live. Thus, an important question is whether the structural conditions of their homes and surroundings stimulate healthier behaviors by individuals and communities. Brazilian municipalities have developed rich experiences with the implementation of Agenda 21 and the MDGs over the past few decades 29 to build a better environment and reach healthy goals. Nonetheless, the public investment reduction and the lack of urban planning raise concerns about the possibility of building healthier cities in the country. For instance, sewage utilities/water supply in Brazil are regulated by the municipalities, and they can delegate the service to specialized agencies. However, recent actions from the Brazilian government favoring actions of private sanitation companies 30 raise concerns, mainly due to the possible consequences to people living in places where the private companies do not see profitable perspectives, which may lead to a scenario of increased inequalities. Moreover, economic inequalities have increased for 17 quarters in a row in Brazil from 2015 to 2019. And an analysis of austerity measures implemented in Brazil revealed that from 2014 to 2017 , the largest proportional reductions in public budgets were in programs targeted at more vulnerable populations 31 . In a country marked by lack of urban planning and deep inequalities, it is worrying when there is shortage of money to plan and implement public policies.

Among the study limitations, we can mention some potential biased information from the interviewee and biased observation from the interviewer. Particularly, the poor may slightly increase their earnings and the rich may decrease them when reporting their incomes and economic conditions in general. As for the interviewer, there may be non-systematic error in identifying the urban characteristics recorded. However, the contingent of people and households analyzed was huge, and the questionnaire and training of the Brazilian census are very rigorously constructed, minimizing errors in data collection.

This study provides relevant information to policy makers and also allows researchers to continue monitoring the social inequalities observed in Brazil. According to the World Health Organization 32, health is one of the most effective markers of any city's successful sustainable development. The surveillance of individual and regional inequalities is paramount in Brazil and should be a priority for the country to achieve the SDGs and to subsidize public policies. 


\section{Contributors}

A. F. Boing and A. C. Boing participated in the study concept and design, data analysis and interpretation and manuscript drafting. S. V. Subramanian participated in the study concept and design, and manuscript critical revision for important intellectual content.

\section{Additional informations}

ORCID: Antonio Fernando Boing (0000-00019331-1550); Alexandra Crispim Boing (0000-00017792-4824); S. V. Subramanian (0000-0003-23654165).

\section{Acknowledgment}

To the Brazilian National Research Council (CNPq; 205120/2018-0).

\section{References}

1. Programa das Nações Unidas para o Desenvolvimento; Instituto de Pesquisa Econômica Aplicada; Fundação João Pinheiro. Atlas de Desenvolvimento Humano. Brasília: Programa das Nações Unidas para o Desenvolvimento/ Instituto de Pesquisa Econômica Aplicada/ Fundação João Pinheiro; 2013.

2. Viacava F, Porto SM, Carvalho CC, Bellido JG. Health inequalities by region and social group based on data from household surveys (Brazil, 1998-2013). Ciênc Saúde Colet 2019; 24:274560.

3. Subramanian SV, Belli P, Kawachi I. The macroeconomic determinants of health. Annu Rev Public Health 2002; 23:287-302.

4. Duncan DT, Kawachi I. Neighborhoods \& health. New York: Oxford University Press; 2018.

5. Rachele JN, Sugiyama T, Davies S, Loh VHY, Turrell G, Carver A, et al. Neighbourhood built environment and physical function among mid-to-older aged adults: a systematic review. Health Place 2019; 58:102137.

6. Singh A, Daniel L, Baker E, Bentley R. Housing disadvantage and poor mental health: a systematic review. Am J Prev Med 2019; 57:26272 .

7. Gascon M, Triguero-Mas M, Martínez D, Dadvand $\mathrm{P}$, Rojas-Rueda D, Plasència $\mathrm{A}$, et al. Residential green spaces and mortality: a systematic review. Environ Int 2016; 86:60-7.

8. Rautio N, Filatova S, Lehtiniemi H, Miettunen J. Living environment and its relationship to depressive mood: a systematic review. Int J Soc Psychiatry 2018; 64:92-103.

9. Chandrabose M, Rachele JN, Gunn L, Kavanagh A, Owen N, Turrell G. Built environment and cardio-metabolic health: systematic review and meta-analysis of longitudinal studies. Obes Rev 2019; 20:41-54.

10. World Health Organization. Shanghai consensus on healthy cities 2016. http://www. who.int/healthpromotion/conferences/ $9 \mathrm{gchp} / 9 \mathrm{gchp}$-mayors-consensus-healthycities.pdf (accessed on 20/Sep/2019).

11. World Health Organization. Investing in water and sanitation: increasing access, reducing inequalities. Geneva: World Health Organization; 2015.

12. World Bank. GINI index. https://data.world bank.org/indicator/SI.POV.GINI (accessed on 09/Jul/2019).

13. Santos M. Espaço e método. São Paulo: Nobel; 1997.

14. Santos G. Relações raciais e desigualdade no Brasil. São Paulo: Selo Negro; 2009.

15. Instituto Brasileiro de Geografia e Estatística. Censo demográfico 2010: resultados gerais da amostra. Rio de Janeiro: Instituto Brasileiro de Geografia e Estatística; 2012. 
16. Instituto Brasileiro de Geografia e Estatística. Censo demográfico 2010: características urbanísticas do entorno dos domicílios. Rio de Janeiro: Instituto Brasileiro de Geografia e Estatística; 2012.

17. Barros AJD, Victora CG. Measuring coverage in $\mathrm{MNCH}$ : determining and interpreting inequalities in coverage of maternal, newborn, and child health interventions. PLoS Med 2013; 10:e1001390.

18. Gasteyer S, Lai J, Tucker B, Carrera J, Moss J. Basics inequality: race and access to complete plumbing facilities in the United States. Du Bois Rev 2016; 13:305-25.

19. Abubakar IR. Factors influencing household access to drinking water in Nigeria. Util Policy 2019; 5:40-51.

20. Mulenga JN, Bwalya BB, Kaliba-Chishimba $\mathrm{K}$. Determinants and inequalities in access to improved water sources and sanitation among the Zambian households. International Journal of Development and Sustainability 2017; 6:746-62.

21. Fay M, Straub S. Rising incomes and inequality of access to infrastructure among Latin American households. Washington DC: World Bank; 2017.

22. Fuller JA, Goldstick J, Bartram J, Eisenberg JNS. Tracking progress towards global drinking water and sanitation targets: a within and among country analysis. Sci Total Environ 2016; 541:857-64.

23. Maricato E. Metrópole, legislação e desigualdade. Estud Av 2003; 17:151-66.

24. Duarte TEPN, Angeoletto F, Santos JWMC, Silva FF, Bohrer JFC, Massad L. Reflexões sobre arborização urbana: desafios a serem superados para o incremento da arborização urbana no Brasil. Revista em Agronegócio e Meio Ambiente 2018; 11:327-41.

25. Silva MC. Arborização urbana de quatro cidades do leste de Mato Grosso do Sul [Masters' Thesis]. Jataí: Universidade Federal de Goiás; 2013.
26. Sartori RA, Martins GAC, Zaú AS, Brasil LSC. Urban afforestation and favela: a study in a community of Rio de Janeiro, Brazil. Urban For Urban Green 2019; 40:84-92.

27. Instituto Brasileiro de Geografia e Estatística. Pesquisa de Informações Básicas Municipais: perfil dos municípios brasileiros. Rio de Janeiro: Instituto Brasileiro de Geografia e Estatística; 2018.

28. Giles-Corti B, Lowe M, Arundel J. Achieving the SDGs: evaluating indicators to be used to benchmark and monitor progress towards creating healthy and sustainable cities. Health Policy 2020; 124:581-90.

29. Westphal MF, Franceschini MC, Setti AFF. How can the healthy municipalities, cities and communities strategy advance the Sustainable Development Goals agenda? Lessons from Agenda 21 and the MDGs in Brazil. In: Azeiteiro U, Akerman M, Leal Filho W, Setti A, Brandli L, editors. Lifelong learning and education in healthy and sustainable cities. Cham: Springer; 2018. p. 265-82.

30. Sousa ACA. World Cup 2018: private water and sewage companies score high in Brazil. Cad Saúde Pública 2018; 34:e00144418.

31. de Souza LEPF, de Barros RD, Barreto ML, Katikireddi SV, Hone TV, Paes de Sousa R, et al. The potential impact of austerity on attainment of the Sustainable Development Goals in Brazil. BMJ Glob Health 2019; 4:e001661.

32. World Health Organization. Copenhagen Consensus of Mayors. Healthier and happier cities for all. A transformative approach for safe, inclusive, sustainable and resilient societies. Copenhagen: World Health Organization Regional Office for Europe; 2018. 


\section{Resumo}

Os objetivos do estudo foram: (1) testar a associação entre os serviços de saneamento básico/ higiene nos domicílios brasileiros e as características socioeconômicas e demográficas dos/das chefes de família e (2) analisar a distribuição dos elementos urbanos relacionados à saúde nos distritos sanitários de acordo com a composição de renda, escolaridade e raça/cor. Os dados foram obtidos do Censo Demográfico de 2010, que coletou informações sobre as condições do domicílio e a infraestrutura urbana dos distritos censitários. Foram calculadas as razões de prevalência, usando modelos de regressão Poisson simples e ajustada. Foi avaliada a distribuição proporcional da infraestrutura urbana nos distritos censitários de acordo com os decis das variáveis exploratórias, $e$ foram calculadas as razões e diferenças absolutas entre os decis extremos. Cerca de 4,8\% dos domicílios não dispunham de água encanada, 34,7\% faltavam esgotamento sanitário, 9,8\% não tinham coleta de lixo e 39\% das moradias eram consideradas inadequadas. Os domicílios chefiados por pretos/as, pardos/as ou indígenas apresentavam niveis mais baixos de renda e escolaridade, e aqueles localizados no Norte, Nordeste e Centro-oeste tinham niveis maiores de moradia inadequada e falta de água encanada, esgotamento sanitário $e$ coleta de lixo. Além disso, os distritos com maioria negra e com menores niveis de escolaridade e renda apresentavam menores coberturas de pavimentação, iluminação e arborização de ruas, galerias pluviais, calçadas e rampas para cadeira de rodas. O estudo analisou os dados de 2010 e estabeleceu uma linha de base para estudos futuros e planejamento de politicas de governo. As desigualdades sociais relevantes relatadas no estudo devem ser enfrentadas com políticas públicas efetivas.

Saúde da População Urbana; Habitação; Saneamento Urbano; Iniquidades

\section{Resumen}

Los objetivos de este estudio son: (1) probar la asociación entre el acceso a servicios básicos de higiene y saneamiento en los hogares brasileños con sus principales características socioeconómicas y demográficas; (2) analizar la distribución de elementos urbanos relevantes para la salud en secciones censales, según la composición de sus ingresos, educación y raza/color. Los datos provienen del Censo Demográfico de 2010, que recogió datos, tanto respecto a las condiciones de los hogares, como al entorno urbano de las secciones censales. Las ratios de prevalencia se calcularon usando modelos de regresión crudos y ajustados de Poisson. Se realizó una distribución proporcional de las secciones censales relacionadas con el entorno urbano, según deciles de las variables exploratorias y las ratios, $y$ se calcularon las diferencias absolutas entre los deciles extremos. Alrededor de un 4,8\% de los hogares no contaban con agua canalizada, 34,7\% no tenían un sistema de alcantarillado, un 9,8\% no tenían recogida de basuras y un 39\% de los hogares fueron considerados inadecuados. Hogares, cuyas cabezas de familia eran negros, indígenas o mulatos/mestizos, tenían bajos ingresos, educación, $y$ vivian en el Norte, Noreste, y Centro-oeste tuvieron más probabilidad de ser considerados inapropiados, no contar con agua canalizada, sistema de alcantarillado y recogida de basuras. Además, los sectores donde la mayoría de la población era negra, con bajos niveles educativos e ingresos más bajos tenían significativamente menos cobertura de pavimentación, iluminación de calles, forestación, alcantarillado pluvial, aceras y rampas de acceso para sillas de ruedas. Este estudio analizó los datos nacionales desde 2010 y proporciona una base de referencia para futuros estudios y planificación gubernamental. Las inequidades relevantes sociales reflejadas en este estudio necesitan que ser tratadas mediante politicas públicas eficientes.

Salud Urbana; Vivienda; Saneamiento Urbano; Inequidades
Submitted on 05/Dec/2019

Final version resubmitted on 02/Oct/2020

Approved on 09/Oct/2020 